\title{
APPLICATION OF SYSTEMS ANALYSIS IN WATER POLLUTION CONTROL: PERSPECTIVES FOR CENTRAL AND EASTERN EUROPE
}

\section{Somlyódy}

International Institute for Applied Systems Analysis, Laxenburg, Austria

RR-92-3

May 1992

Reprinted from Water Science and Technology (1991) 24(6):73-87.

INTERNATIONAL INSTITUTE FOR APPLIED SYSTEMS ANALYSIS Laxenburg, Austria 
Research Reports, which record research conducted at IIASA, are independently reviewed before publication. However, the views and opinions they express are not necessarily those of the Institute or the National Member Organizations that support it.

Reproduced from Water Science and Technology (1991) 24(6):73-87 with kind permission from Pergamon Press Ltd., Headington Hill Hall, Oxford, OX3 0BW, UK.

Copyright (C)1991 IAWPRC.

All rights reserved. No part of this publication may be reproduced or transmitted in any form or by any means, electronic or mechanical, including photocopy, recording, or any information storage or retrieval system, without permission in writing from the copyright holder.

Printed by Novographic, Vienna, Austria. 


\section{Preface}

IIASA has a long history of the application of systems analysis in water resources research and management. This paper continues this tradition and includes the following:

- The consideration of the application of systems analysis in pollution control.

- The situation in Central and Eastern Europe, i.e., in transitional economies.

- A discussion of the results of the restoration program of Lake Balaton, to the development of which IIASA's research contributed significantly ten years ago. (Balaton served as the major case study for the shallow lake eutrophication management project.)

LÁSZLÓ SOMLYÓDY Leader

Water Resources Project 


\title{
APPLICATION OF SYSTEMS ANALYSIS IN WATER POLLUTION CONTROL: PERSPECTIVES FOR CENTRAL AND EASTERN EUROPE
}

\author{
László Somlyódy \\ Water Resources Research Centre, VITUKI, 1095 Budapest, Kvassay Jenó út 1., \\ Hungary
}

\begin{abstract}
Recent major political changes in Central and Eastern Europe opened new avenues for environmental and water quality management. In the past there was practically no need for the application of systems analysis or any policy-related sciences. As an exceptional case the eutrophication control of Lake Balaton (Hungary) is discussed. The counterpart example is the Gabcikovo-Nagymaros barrage complex (Danube): here a systematic assessment is missing even today. The type of the analysis which would be required is illustrated by two examples: eutrophication of the upstream reservoir of the complex and oxygen household of one of the side arms of the Danube. Future applications of systems analysis depend primarily on desired institutional changes and environmental legislation, as due to past economic development paths large number of problems exist in Central and Eastern Europe. These are discussed primarily for Hungary. Skill and scientific knowledge exist but experiences in application are lacking. Environmental education should be modernized. A specialized technology transfer is needed also towards changes of institutional structures and legislation, and also the training of managers. The most important task under the existing economic pressure is the preparation of well tailored, cost-effective water pollution control strategies for countries in question. This requires in itself a systems analytical approach.
\end{abstract}

\section{KEYWORDS}

Systems analysis, modeling, environmental and water quality management, policy making, legislation, Central and Eastern Europe, Hungary, Lake Balaton, Danube, the Gabcikovo-Nagymaros river barrage system, eutrophication, oxygen household.

\section{INTRODUCTION}

Quade and Miser (1985) describe systems analysis as a concept "to investigate how to best aid a decision or policy maker faced with complex problems of choice under uncertainty, a practical philosophy for carrying out decision-oriented interdisciplinary research and a perspective on the proper use of the available tools". From this broad definition it follows (a) that the final objective is to conclude on a decision (related to a water pollution problem in our particular case) and (b) this can be achieved if conditions and willingness are given for the meaningful cooperation of two groups of actors, namely analysts and policy makers (such a collaboration is not easy and for this reason not too many successful applications are known in the literature).

The behaviour of policy makers on various levels very much depends on institutional affairs, laws, 
legislation etc. or in short on the actual political system and establishment. The same statement should also apply to development of water pollution control strategies: the indirect impact of politics is probably higher than that of any scientific discoveries.

The socialist political system has collapsed in 1989 within a couple of months in Central and Eastern Europe. Obviously, this has created an opportunity to change environmental policy and water quality management and consequently opened new avenues for the application of systems analysis. There is no answer at the moment whether the former socialist countries can cope with the unique historical situation (associated with economic disaster). Similarly, we cannot answer the inter-related question whether the changed political conditions will really lead (and when?) to successful applications of systems analysis in water pollution control. However, what we can do is to think and speculate on identifying needs and opportunities for future applications. We will start our discussion, as usual, with past experiences.

\section{PAST EXPERIENCES}

It is our intention to avoid offering a biased view on the operation of the earlier political system and its consequences in Central and Eastern Europe. Nevertheless, it is realistic to state that economic planning and policy making was quite different from in countries of market economy. As far as environmental and water quality management is concerned objectives have been loosely defined in most of the cases; instead of selecting and analysing alternatives, "the solution" was pointed out at the beginning and consequently there was no need for an economic or multi-objective evaluation. Identification, assessment, screening, selection etc. of project alternatives were all unknown in practice as decision was the task of the "all-knowing" central government. Economic losses caused by incorrect decisions were compensated from the state budget, meanwhile centralizing the major part of profits from successful undertakings and finally, external loans were used to retrieve deficits of the state budget (rather than to modernize technologies applied in industry, energy production and agriculture). Under such conditions it is not a surprise that e.g. in Hungary no multiobjective water resources project assessment or environmental impact assessment of a well defined role in policy making is known. Under such circumstances any application of systems analysis (or other methods, concepts, sciences etc. related to policy making) should be considered as an exception rather than overall practice.

Thomann (1987) offers a somewhat narrower (less policy oriented), but in certain senses preciser definition of systems analysis (in water pollution control) than Quade and Miser (1985): it is "the engineering art of integrating and synthetizing the physical, chemical, biological and mathematical sciences with the social and economic sciences to construct frameworks that elucidate the consequences of alternative water quality and water use objectives" and he adds that the construction of mathematical modeling frameworks is a key element of the entire procedure.

If we analyze the state-of-the-art of water quality modeling in Central and Eastern European countries, the picture is much better than for systems analysis. It suffices to refer to internationally well received professionals such as Gnauck, Uhlmann, Maursberger, Straskraba, Gromiec, Vasiliev, Svirezhev and their co-workers (see e.g. Uhlmann, 1982, Orlob, 1983, Straskraba and Gnauck, 1985). Their activity, however, remained research-oriented, and policy applications are practically unknown.

It was said earlier that for the application of systems analysis only exceptional examples exist. Such a case is the eutrophication management of Lake Balaton in Hungary. This "success story" will be outlined subsequently. The counterpart will be the Gabcikovo-Nagymaros river barrage complex on the Danube illustrating consequences of lacking appropriate policy making procedure.

\section{Eutrophication management of Lake Balaton}

Lake Balaton, one of the largest shallow lakes in the world, is the most important recreational area in Hungary (Fig. 1), an outstanding national asset. The case of the lake is considered well known from the literature (Somlyódy and van Straten, 1986). 
The cause of man-made eutrophication of Lake Balaton was three-fold: (a) the increase in tourist load; (b) intensification of agricultural production in the watershed and (c) the much faster development of public water supply than that of sewerage network and waste water treatment. These factors contributed to an order of magnitude increase in nutrient loads of the water body between say, 1960 and 1980.

First symptoms of artificial eutrophication in Lake Balaton were recognized as early as the mid-1940s. Still, the judgement of policy makers remained optimistic and their concern started to grow only around the early eighties, subsequent to two major fish-kills and unfavourable changes in phytoplankton structure. A dramatic sign of the latter was the mass invasion of a filamentous blue-green species, Anabaenopsis raciborskii in the summer of 1982 .

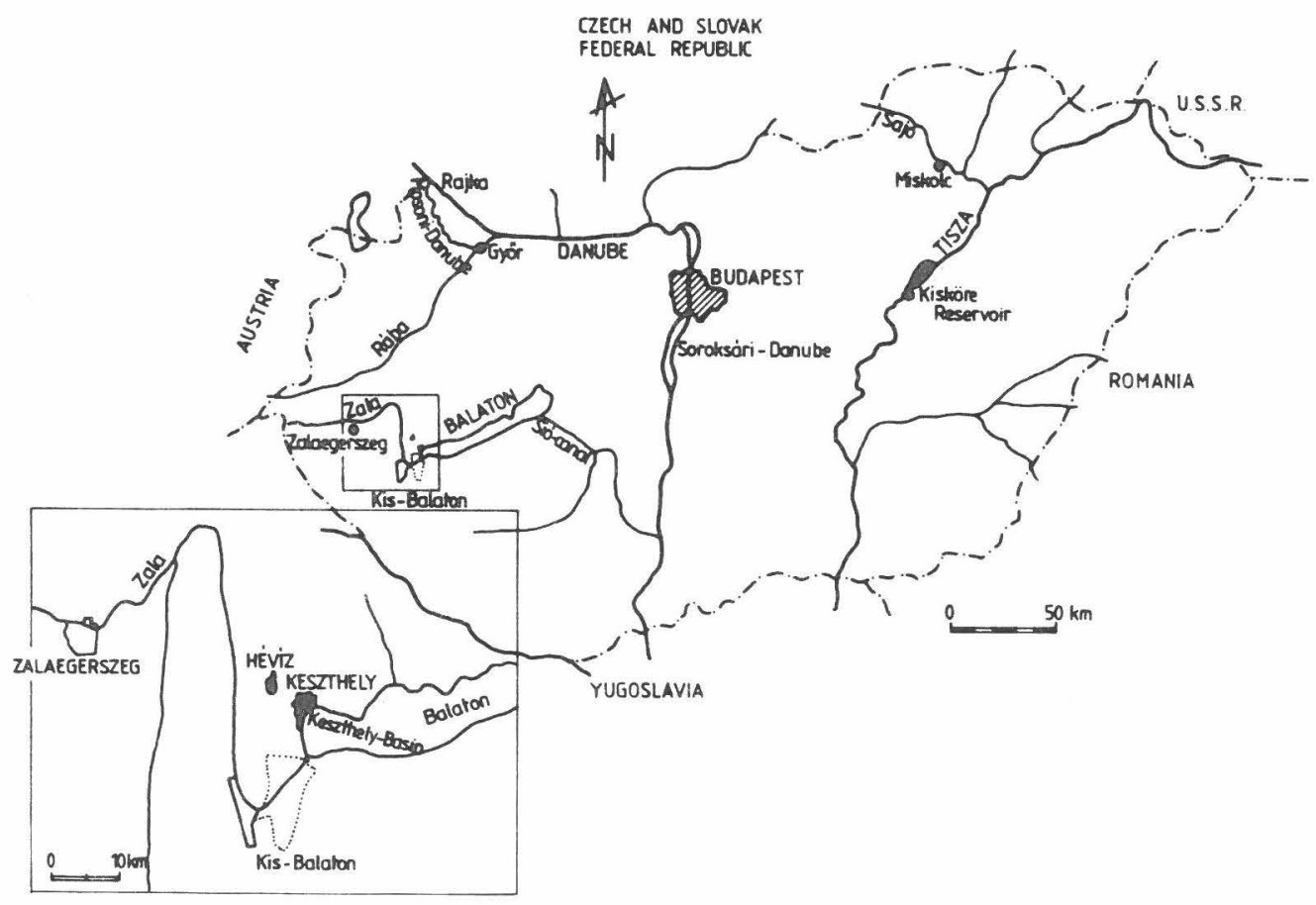

Fig. 1. Map of Hungary.

Lots of disciplinary research results have been available for 1978 when the lake was selected as the major case study example for the shallow lake eutrophication project (1978-1982) of the International Institute for Applied Systems Analysis (IIASA). The objective of the first half of the cooperative study with several Hungarian institutions - as it is formulated today - was to synthesize knowledge belonging to different disciplines with the aid of a modeling framework (phase of understanding), while the second stage was policy oriented as the need and opportunity was recognized (phase of planning and management). Developments included, among others, ecosystem models, computation of wind-induced water motion and sediment resuspension, a coupled hydrophysical-ecological model, evaluation and modeling nutrient loads and different kinds of eutrophication management (optimization) models (see Somlyódy and van Straten, 1986, Somlyódy and Wets, 1988). For early 1982 details of the optimal short-term eutrophication management strategy were available including the spatial configuration of control measures, budgeting, priorities and expected water quality improvement associated (expressed in terms of annual peak value of chlorophyll-a concentration). It is noted that control variables of the decision model represented "protective" actions such as upgrading biological sewage treatment, the introduction of phosphorus precipitation or the 
construction of pre-reservoirs for controlling nutrients of agricultural non-point-source origin. Obvious conflicts and trade-offs among agricultural production, tourism and environmental protection were not treated, as sectorial considerations did not allow it and institutional conditions were lacking (as is the case in most of the countries even today).

The Council of Ministers launched a policy making procedure at the same time (early 1982). It was a multiactor game since representatives of three counties and three district water authorities of the Balaton region, and ministries and agencies such as the National Water Authority, the State Office for Environmental Protection and Nature Conservation, the Hungarian Academy of Sciences (HAS), the State Office for Technology Development, the Ministry of Agriculture, the Ministry of Home Trade and the Ministry of Building Construction and Regional Development participated in addition to members (expressing their own professional views) of expert committees formed under the umbrella of HAS.

About half a year was spent with meetings and negotiations of strong pressures from various sides. Some of the agencies formed their official point of view in advance and expected (stressed) that experts belonging to their institutes would represent this opinion. The Ministry of Agriculture launched a monitoring program and "justified" that the contribution of non-point sources to the total load of the lake was negligible (sampling during rainfall events was avoided).

Lobbies of different natures happened to form. One argued that the quality of water was actually improving. The other was against any conclusion coming out from modeling exercises. The third doubted that phosphorus removal would have any positive impact. Lots of government officials agreed that analysts must not deal with economics and cost-effectiveness but just ecology and water quality.

In spite of these difficulties the end result was unique in Hungary: the government made a decision early in 1983 which incorporated consistent short- and long-term objectives for the time span 1983-2010 (in terms of phosphorus loads and chlorophyll-a concentrations for various basins of the lake), measures to be taken, budgeting and monitoring (Láng, 1986).

Most of the control measures prescribed by the end of 1987 have been realized. Upgrading, phosphorus precipitation and disinfection were introduced in 10 sewage treatment plants, the regional sewage network and treatment system was developed considerably and the first segment (about $20 \mathrm{~km}^{2}$ surface area) of the Kis-Balaton reservoir at the mouth of the Zala River (Fig .1) draining half of the lake's watershed has been established.

There were two items of the original plan that were not realized by the intended deadline: the phosphorus removal at the treatment plant of the largest city of the region, Zalaegerszeg (Fig .1) only started to operate in 1990 (because of technical difficulties and institutional reasons) and the construction of the second segment of Kis-Balaton (Fig. 1) was postponed due to financing problems.

As a result of the control measures taken, the total amount of phosphorus entering the lake has been halved and deterioration of water quality has been stopped. However, no improvement could be observed until now, and in the most eutrophic Western region of the lake still peak chlorophyll-a concentrations close to 150 $\mathrm{mg} / \mathrm{m}^{3}$ can be observed in late summer (Fig. 2). The explanation for this is twofold: (a) the high internal phosphorus load approximately corresponding to the external one of the early eighties (justified not only by earlier modeling exercises but also by isotope experiments, Istvánovics, 1988) and (b) the dominance of nitrogen-fixing blue-green algae (in other words interface processes between sediment and water, and air and water determine water quality in the present stage of eutrophication of the lake).

Due to excess nutrient supply and dominance of light limitation, the performance of ecological models is much better than for the late seventies (Farkas, 1990). This is well reflected by Fig.2 showing observed and simulated chlorophyll-a concentrations for the Keszthely basin (Fig. 1). The BEM model (including four algae groups and six other state variables) developed by Kutas and Herodek (1986) have been applied. 1988 was used for calibration, while 1989 for validation (forcing functions such as temperature, solar radiation, 
nitrogen and phosphorus loads have been derived from daily measurements). Parameters obtained were practically the same as published earlier, just the growth and death rates, and moreover the optimal temperature of blue-green algae have been changed slightly. It is interesting to note that as contrasted to earlier years no spring algal peaks have been observed (Fig. 2).
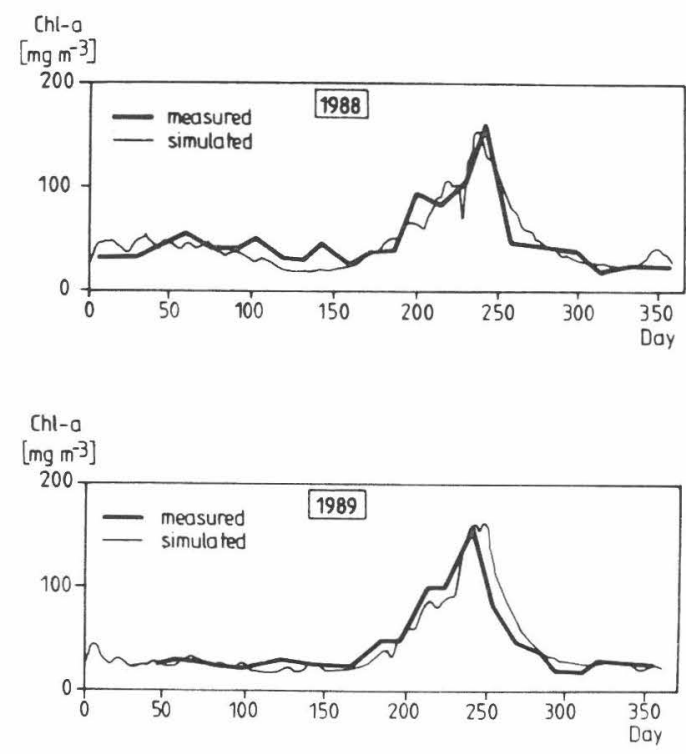

Fig. 2. Simulated and measured chlorophyll-a concentrations for the Keszthely basin (Lake Balaton).

\section{The Gabcikovo-Nagymaros barrage system}

The Hungarian and Czechoslovak governments had been considering the establishment of a complex hydropower scheme on the Danube reach upstream of Budapest even since the early fifties. After long lasting negotiations of the two parties a conceptual agreement on the implementation was reached in 1973 . The inter-governmental contract of construction was signed in 1977. According to the favoured concept selected from several alternatives born in the early fifties the scheme consists of two low-head hydropower plants (see Fig. 3). The upper part includes a reservoir of about $200 \times 10^{6} \mathrm{~m}^{3}\left(62 \mathrm{~km}^{2}\right)$ at Dunakiliti, a 25 $\mathrm{km}$ long power canal diverting the flow of the river to the turbines of the Gabcikovo power station (the discharge capacity is $5200 \mathrm{~m}^{3} / \mathrm{s}$ and the old Danube used as a flood way. According to these plans $50 \mathrm{~m}^{3} / \mathrm{s}$ minimum discharge would be released to the old Danube (the multi-annual average flow of the Danube at Bratislava is approximately $2000 \mathrm{~m}^{3} / \mathrm{s}$ ) which is to be increased to about $200 \mathrm{~m}^{3} / \mathrm{s}$ until the power canal reaches Danube. This additional flow is contributed by side arms of the river, receiving supply from interception canals of both sides of the reservoir and also by the Mosoni-Danube branch.

The Gabcikovo power plant was to be operated in peaking mode with a capacity of $720 \mathrm{MW}$ (release takes place normally twice per day, depending on the actual flow).

The other component of the scheme at Nagymaros (Fig. 3) would have two functions in addition the generation of $160 \mathrm{MW}$ power: (a) it is to secure the navigational draft waterway prescribed by the Danube Commission and (b) it is to attenuate the strong water level fluctuations caused by peaking operation of the upstream power station.

The brief chronology of events related to environmental issues of planning, construction and policy making is as follows. 


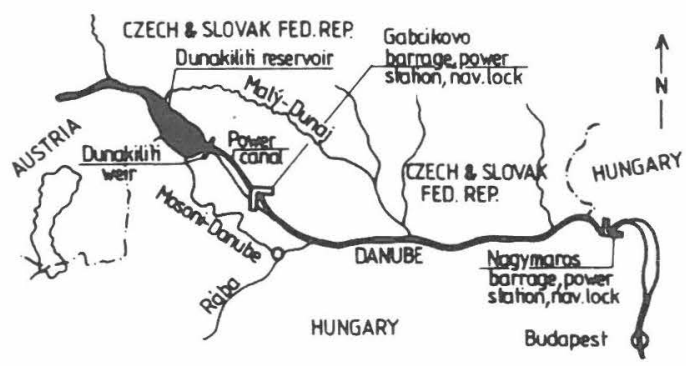

Fig. 3. Scheme of the Gabcikovo-Nagymaros river barrage system (Danube).

1976: The Terminal Report of a UNDP/WHO (1976) project dealing with water quality management calls attention to possible negative impacts of the barrage system on the water quality of the Danube.

1976-1978: VITUKI and the Danube Research Station of the Hungarian Academy of Sciences recommend to launch a comprehensive research program to study the above impacts. There is no response from policy makers: they do not share the concerns.

\section{8: Construction works start.}

1982-1984: The freshly born movement of the Hungarian greens concentrates their efforts in attacks against the river dam project. The concern of society is growing. Among others, endangering bank filtered water resources, natural water treasures and ecosystems, deterioration of water quality, loss in genetic resources and historic and aesthetic values can be listed. The government does not react properly even prohibiting open dialogues.

1983: The construction on the Hungarian side was suspended because of lack of budget and environmental concern.

1985: An "environmental impact assessment" was elaborated under the coordination of the planning office which was in charge for the design from Hungarian side. The procedure considers the single alternative decided upon earlier. The report incorporates no quantitative statements on water quality, and doubts raised remain unanswered. A comprehensive cost-benefit analysis is also missing.

1986: The construction was accelerated after signature of a contract between Hungarian and Austrian companies on Nagymaros barrage (also credit was guaranteed by the Austrian government).

1988: The government informed the parliament about the situation with construction of the dam complex. As contrasted to the original objective of maximizing energy production the need for ecologically safe operation was emphasized for the first time. Investment cost was estimated to be about $50 \times 10^{9} \mathrm{Ft}\left(\sim 10^{9}\right.$ USD) which might be doubled due to additional costs of water- and waste water treatment and other measures to be taken to compensate likely adverse impacts of the dam complex. In spite of demonstrations against the barrage system the parliament approved the continuation of construction.

1989: After more than a hundred thousand signatures have been collected by alternative movements against the dams the parliament had to re-consider the issue. This led to the cancellation of the Nagymaros river barrage under construction (together with the peak operation mode of the Gabcikovo power station as a consequence) and the suspension of the construction of the upstream barrage (95\% of which was already completed).

1990: The new Hungarian government declared its intention in its program for avoiding to put into operation the Gabcikovo power station. At the end of the year it was decided to initiate negotiations with the 
government of The Czech- and Slovak Federal Republic to modify the intergovernmental contract signed in 1977.

Retrospectively we may argue that the failure of the Gabcikovo-Nagymaros project is due to the lack of the application of systems analysis. In spite of performing detailed analyses on hydraulics, hydrology and other issues, the synthesis of different disciplines as stressed by Thomann "to construct frameworks that elucidate the consequences" of the project did not take place and this is particularly true as water quality and ecologiceconomic implications are concerned. Taking the definition of Quade and Miser, simply there was no need from the side of policy makers to aid their decisions.

Which kind of analyses would have been desired? We tried to illustrate it in a "home work" report (Somlyódy et al., 1989) in which we studied primarily two problems (subsequent to a comprehensive evaluation of existing data and knowledge on the water quality of the Danube reach in question):

(a) eutrophication in the upper reservoir and

(b) oxygen household in the Mosoni-Danube (Fig. 3) under peak operation mode (the side-arm is the recipient of the sewage water from the city of Gyor which has more than 100000 inhabitants).

A classical eutrophication model (see e.g. Thomann and Mueller, 1987) was used for the first case (the through-flow reservoir was subdivided into three parallel channels: the main river bed and two flood-plains), while a coupled ID hydrodynamic-transport Streeter-Phelps model (capable of handling back-and-forth flow) was used for the second one. Detailed sensitivity and uncertainty analyses have been also performed since we basically had to rely on literature data.

Subsequently a summary of this study will be given.

During the past three decades the nutrient loads across the Rajka section of Danube (where the river enters Hungary) has been increased by 5-10 fold, due to upstream pollutant discharges. Transparency of the river was improved due to upstream impoundments. These effects together resulted in an increase of the algae count of an order of magnitude. Today the chlorophyll-a concentration is $50 \mathrm{mg} / \mathrm{m}^{3}$ on average (with peak values exceeding $100 \mathrm{mg} / \mathrm{m}^{3}$, Fig. 4) and increases with the distance downstream. Due to the storage in the upstream reservoir of the project, the average flow velocity will be decreased to one-fourth or one-fifth, increasing the theoretical residence time to 17-68 hours, as a function of the incoming flows. Simultaneously, the deposition of suspended sediment increases, thus improving light conditions.

Taking also the existing excess nutrient supply conditions into consideration the modeling exercises resulted in doubling of the end of the summer algal biomass, and chlorophyll-a concentrations exceeding $200 \mathrm{mg} / \mathrm{m}^{3}$ might also occur in floodplain parts of the future reservoir.

Uncertainties of the above prediction related to model parameters are high particularly for floodplain regions of shallow depth, thick photic zone and high residence time. These factors explain why Monte Carlo simulations resulted in extreme chlorophyll-a concentrations as high as $500 \mathrm{mg} / \mathrm{m}^{3}$ (distributions obtained are typically skewed). The respective outflow concentrations would be about $200 \mathrm{mg} / \mathrm{m}^{3}$.

A detailed prognosis for the eutrophication of the reservoir would require among others the derivation of the upstream boundary (or initial) condition as a function of hydrologic and meteorologic factors. For this purpose a simple algae model has been developed by using daily temperature, solar radiation and stream flow data for the period 1976-1986. Spring and late summer algae groups have been introduced (for temperature limitation factor see Kutas and Herodek, 1986). Algal dynamics have been described by using the traditional approach on the basis of the Lambert law and Steele equation (see e.g. Thomann and Mueller, 1987) and assuming that nutrients are not limiting. Reactions have been introduced into a simple ID equation for convective transport. Upstream river system was replaced by an equivalent (lumped) river stretch the length of which is considered to a model parameter (the usefulness of this hypothesis is likely because of the presence of excess supply of nutrients). Model parameters have been estimated by applying a Monte Carlo 
procedure subsequent to defining the behaviour of the system (see Hornberger and Speer, 1980).

The year 1976 was used for calibration with the rest of the data set for validation. Depending on the coincidence of different hydrologic and meteorologic events quite different behaviours can be observed: the number of pronounced algal peaks varies between one and four, but for certain years only a noise-type change can be identified.

Figure 4 illustrating measurements and simulations for 1976 and 1986, justifies the surprisingly good performance of the model developed.

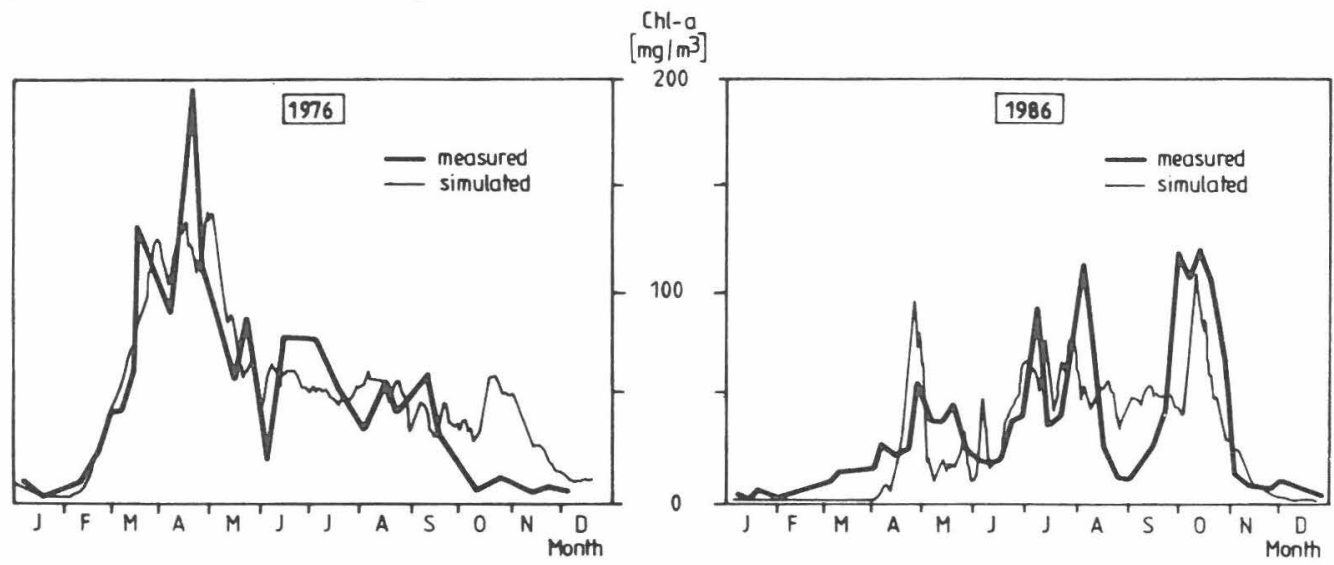

Fig. 4. Computed and measured chlorophyll-a concentrations: Danube at Rajka.

Returning to the impact of the upstream reservoir, increased algal biomass estimated would result in raising internal loads of organic matter. As contrasted to organic loads of sewage origin this secondary load will increase with the downstream distance (in the growing season) due to the fact that growth rates exceed mortality rates. This means that a relatively long downstream reach of the river will be affected by these impacts. These effects would further be amplified by the construction of the Nagymaros reservoir that would induce some additional algal growths.

As a result of all these above effects the organic load, expressed in terms of COD or BOD, would increase in the vegetation period even if all sewage discharges of the drainage basin downstream of Rajka were biologically treated.

Increased algae counts or the secondary contamination due to decaying algae would certainly require the modification of the present water treatment technologies of the surface water intake works of Budapest. Increased organic loads will also unfavourably affect the processes of bank-filtered well-based drinking water production. The development of anaerobic conditions in the sediments will be favoured, thus giving more chance for the occurrence of ammonia, manganese and dissolved iron in the water produced. The occurrence of these substances will require the modification of the water treatment technology with additional technological processes.

It is noted if the downstream barrage and the peak operation mode of Gabcikovo are cancelled, the practically ready-made large upstream reservoir (not yet filled up) leading to eutrophication problems is unnecessary.

The assessment of future water quality conditions is very much complicated by the peak operation mode planned originally. An exception is the oxygen household in the Mosoni-Danube heavily loaded by the sewage of Gyór (Fig. 3). Here, the increase in the daily average dilution would at first sight lead to improved dissolved oxygen conditions. However this is not the case as justified by our modeling effort, since the tidal- 
like back-and-forth motion results in significant increase in the local residence (or travel) time. The application of the Streeter-Phelps model for unsteady flow stemming from peak operation has shown (Somlyódy et al., 1989) that even under the condition of biological treatment of the sewages of the city of Gyór minimum DO concentrations around $3-4 \mathrm{~g} / \mathrm{m}^{3}$ can occur (Fig. 5) (the absolute value of the velocity is about $0.4-0.5 \mathrm{~m} / \mathrm{s}$ all the time, however the flow changes direction twice a day: there is a downstream flow for the periods $0-8$ and $14-24 \mathrm{~h}$, while a reverse one in between). Under stormwater conditions oxygen depletion will take place unless proper equalization or diversion to Danube are not realized (Fig. 5).
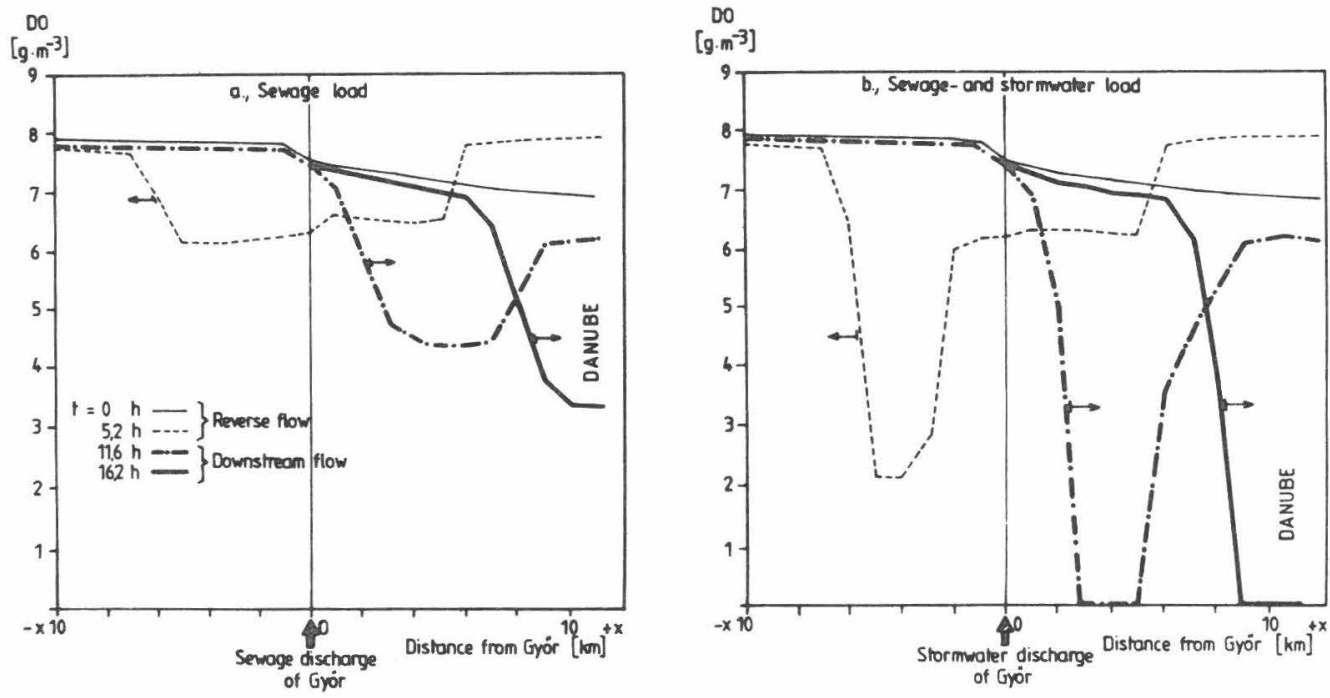

Fig. 5. Changes of dissolved oxygen levels in the Mosoni-Danube due to peak operation of the GabcikovoNagymaros river barrage system.

The two examples outlined have clearly illustrated that (a) a systematic, multi-disciplinary modeling approach is obviously needed to analyse the impacts of such a large-scale, complex project; and (b) at present very loose and uncertain answers can be given to lots of questions raised in relation to future changes in water quality and consequently suspension of the construction was the only correct decision assuring time to perform the missing analyses.

The Gabcikovo-Nagymaros project was handled by previous governments as a political issue. The judgement of the new government is just the opposite to that of the earlier ones, but open questions and doubts related to environment have even so not been analyzed and answered scientifically, just as in the past. The only acceptable professional way would be to launch an environmental impact assessment which would start from the present situation as recommended by a committee of the Hungarian Academy of Sciences in early 1990 . However, there seems to be very little space for such a systematic analysis and decision support. The issue is still too hectic politically and emotionally; denying of the project is the only accepted step, but not a well designed policy-making procedure.

It is noted that the cancellation of the dam system would leave the problem of low flow navigation open in certain river reaches: the opening of the Danube-Main-Rhine international waterway navigation will likely amplify this issue.

\section{FUTURE NEEDS AND OPPORTUNITIES}

Future applications of systems analysis in environmental and water quality management depends at least on three major factors as follows: 
(1) type of problems to be solved;

(2) institutional structures and legislation;

(3) knowledge and experience available (which define needs for training and technology transfer).

Subsequently these issues will be discussed.

\section{Problems to settle: state of the environment in Eastern Europe and Hungary}

Decisive economic paths in countries of centrally planned economics (CPE) have been quite different for the past 40 years to those in Western Europe. They underwent rapid industrialization, urbanization and, to different extents, the intensification of agriculture. Most of the changes occurred without regard to environmental impacts. The overforced, extensive economic development of high raw material and energy consumption was associated with a lack of concern for waste production. As a result, environmental pollution has become a serious problem.

As an example, let us briefly consider the development of energy production.

In the former CPE countries, the annual average growth rate of energy consumption was close to $6 \%$ from 1950 to 1980, double that in industrialized countries (Darmstadter, 1986). More striking is the comparison if we selected the period 1973-1980; $6 \%$ against $0.5 \%$ (the contribution of coal to the total energy production is still $50 \%$ ). Since 1950 a 3 -fold growth has been observed in $\mathrm{CO}_{2}$ emission (contributing to global warming); at present the Eastern part of Europe discharges about twice as great an amount of $\mathrm{CO}_{2}$ as does Western Europe. Sulphur emission and deposition data are also well reflecting the difference in energy structure between East and West: according to the European Monitoring and Evaluation Programme ( EMEP, 1989) in 1985 the highest emission was observed in GDR, followed by Czechoslovakia, Hungary, Belgium, UK, Poland, Bulgaria and FRG. Pollution export exceeds import for all the former CPE countries contributing to serious transboundary air pollution problems such as acidification.

Very little systematic information is available for the state of quality of the environment (including water) of Central and Eastern European countries (an exception is Hungary where a relevant book was published in 1990, see Hinrichsen and Enyedi, 1990), but it is evident that a vast number of problems must be solved in the future. Subsequently we deal with Hungary (for details see Hock and Somlyódy, 1990).

Industry is the largest water user and polluter at the same time. About $20 \%$ of the effluents are treated adequately while approximately the same amount remains untreated. Communal water supply has been developed to about $85 \%$ since 1945 ; however the ratio of public sewerage is less than $50 \%$. Biological sewage treatment is well below the latter level and $1.3 \times 10^{9} \mathrm{~m}^{3}$ of untreated waste water is discharged into recipients annually, polluting rivers, lakes and groundwater aquifers.

Nitrate accumulation in groundwater (often associated with bacteriological contamination) is one of the most serious problems: in about 700 settlements (containing some 300000 inhabitants) emergency measures (e.g. distribution of bottled water) had to be taken. The increase in fertilizer application contributes not only to the nitrate problem but also to eutrophication of surface waters.

In Hungary, $80 \%$ of drinking water supply depends on subsurface water. As an example more than $85 \%$ of the water supply of Budapest stems from bank-filtered water resources (upstream and downstream of the capital). About $20 \%$ of groundwater resources (50-600 m depth range) is of Class I and only half of potable water is protected adequately. In addition to nitrate, arsenic contamination, methane, iron and manganese can cause problems, depending on regions.

As far as surface waters are concerned, $94 \%$ of them originate from abroad, which calls for international cooperation in water and water quality management. On the basis of parameters of oxygen and nutrient households, about one-third of river cross-sections monitored have shown an improvement (1976-1985) due to control measures taken; less than half of them proved to be of Class I and poor quality (Class II or III) was associated with significant deterioration ( $>3 \% / y e a r$ ) in about $15 \%$ of the cases. The extent of the nitrate 
problem is clear also here: in $87 \%$ of the sampling stations worsening has been observed.

The quality of the Danube (Fig. 1) shows a stagnant character for the past 15 years (Class II for the chemical parameters). The quality of the River Tisza (Fig. 1) is continuously deteriorating (both, in time and longitudinally). The same statement applies for the few medium-size rivers, the catchment area of which is located completely within Hungarian territory.

From a policy point of view we can draw the following conclusions:

(a) the downstream country character calls for a smooth cooperation in water management with neighbouring countries;

(b) pollution problems are less serious than in other former CPE countries;

(c) problems appear in a dispersed way in the country following the spatial distribution of urban and industrial centres;

(d) no dramatic problem exists which should be solved first and priorities cannot be easily pointed out;

(e) investment requirements are enormous: it suffices to mention that just the development of sewerage system and waste water treatment would necessitate 3-5 $\times 10^{9}$ USD (the situation is probably worse for Poland and The Czech and Slovak Federal Republic.

The summary conclusion is that a well tailored, country-wide water pollution control strategy is needed (for all the Central and Eastern European countries) by defining short- and long-term objectives and priorities. Under the existing economic constraints the preparation of such a program is extremely difficult and it requires in itself a systems analytical approach.

There exist a number of regional problems calling also for the application of systems analysis. For Lake Balaton, as noted earlier, measures of the first phase of the remedial programme have been taken. However, their effectiveness has not been evaluated, neither have steps needed to meet the targets of the second stage of the original programme been specified. In the meantime new problems have shown up e.g. the drinking water supply by treatment of lake water of high blue-green algae biomass. Water shortage due to droughts (characteristic for the past eight years) can be also mentioned here together with the reduction of inflow at the North-Western region of the lake (Fig. 1) due to abolishing bauxite mining and associated water extraction (extracted water was discharged to the lake). Bauxite mines were closed because of the dramatic reduction of the thermal water supply of Lake Héviz (close to Keszthely), one of the largest lakes fed by thermal springs in the world.

The example of the Kis-Balaton reservoir (Fig. 1) can be also mentioned here. A system of interactive models (incorporating components for rainfall-runoff, ID unsteady flow and phosphorus cycling) is under elaboration with the aim to assist the day-to-day operation: objectives are to keep the water level as constant as possible (because of macrophytes) and to maximize phosphorus removal (Szilágyi et al., 1988).

The example of the Gabcikovo-Nagymaros barrage system was discussed at length earlier: negotiations between the two countries for finding a compromise solution would require the systematic analysis of various alternatives.

There is an additional issue to be mentioned in relation to the Danube: the impact of Budapest on the river's quality. The water supply of the capital depends primarily on bank-filtered groundwater resources (see earlier). At the same time only $20 \%$ of the waste waters of the capital is treated biologically, the fate of the rest relies on the high dilution and self-purification capacity of the Danube. Indeed, the difference in parameters of $\mathrm{COD}$ or $\mathrm{BOD}_{5}$ between downstream and upstream cross-sections of Budapest is negligible, but a marked increase can be found in heavy metals (the contribution of industrial waste waters is significant) and bacteriological parameters. This is also the case for bank filtered water resources: about $47 \%$ of well water is of consistently poor quality in the southern well fields (characterized by high levels of nitrate, iron, manganese and ammonia - the latter three due to near anaerobic conditions in the sediment), while it is only 9\% for the northern fields (Hock and Somlyódy, 1990). For the above reason, water pumped from the southern fields $\left(10^{5} \mathrm{~m}^{3} / \mathrm{d}\right)$ requires advanced ozone treatment. 
The policy dilemma covers treatment of communal and industrial sewages, protection of bank-filtered water resources, maintaining (improving) the recreational value of the Soroksár-Danube downstream of Budapest, improvement the overall quality of the Danube, and the sequence of measures to be taken under given financial constraints. The answer requires careful analyses: which actions should be scheduled for the future in order to avoid a crisis in one or two decades.

The last example we refer to is the Sajó River Valley (Fig .1) in the Northern Middle Mountains. This is one of the most heavily industrialized regions of the country (about $10 \%$ of the total industrial production stems from here) characterized by iron and steel, metallurgical works, cement and concrete panel production and glass making. A significant petrochemical complex can also be found in the region together with several cities (including Miskolc, the second largest town in Hungary) of inadequate waste water treatment. As a consequence of all these together with upstream pollution (of communal and industrial origin) coming from The Czech and Slovak Federal Republic the River Sajó has perhaps the poorest quality (Class III) in Hungary (characterized among others by high concentrations of $\mathrm{COD}, \mathrm{NH}_{4}{ }^{+}, \mathrm{NO}_{3}{ }^{-}, \mathrm{PO}_{4}{ }^{3-}$, heavy metals, oil and lignite compounds) influencing negatively the quality of the Tisza River and the downstream Kiskore reservoir. If we consider also water availability and distribution problems, the management is a complex, regional problem. It is not by accident that the River Sajó was selected at the early seventies as one of the pilot zones of the first UNDP/WHO project dealing with advanced water quality management in Hungary. In fact a regional optimization model incorporating the 17 largest sewage discharges has been developed (Bora et al., 1977) but no implementation took place.

\section{Institutions and legislation}

Central and Eastern European countries are at present in a difficult transition period. There is a unique opportunity to change significantly environmental policies and practices according to actual needs and not necessarily by copying industrialized countries. However, there is also a large amount of danger: if reshaping is not realized properly now, several decades can be lost.

The situation is difficult because the shift towards the market economy is obviously associated with a strong decentralization of the earlier political system, unclear property relations, significant privatization, the rapid growth of small enterprises (focusing primarily on economic growth and not on possible adverse impacts on the environment) and the transfer of Western technologies (which are unfortunately often of low quality leading to pollution).

The opportunity is given to link the re-shaping of the economy with the regulation of environment as this is the only way to prevent pollution and to achieve long-term cost-effective solutions on the national level. At the same time, however, economies of Central and Eastern European countries are in such a bad shape that governments might be forced to think of the short term as happened in the past and to continue considering environmental management as an external factor to the economy. The other real danger is that decentralization imposing much more power on local authorities and governments will take place prior to elaborating environmental strategies, setting objectives and priorities and defining the role which the government wants to maintain for the future.

The present situation is particularly confusing in Hungary where a separation of environmental protection and water management has been initiated in 1990 (it is noted that they were joined recently, in 1988). The underlying cause is the issue of the Gabcikovo-Nagymaros barrage system referred to earlier several times (often called a "national tragedy") which is an example for a water project of likely adverse impacts on the environment. It is also an example of the operation of an institutional hierarchy which did not involve any "watch-dog" functions for such a case and consequently the decision of the new government on the separation was a step satisfying both the society and all the political parties. From the point of view of professional aspects of environment and water management the decision was arguable, but experiences from other countries show that many different systems can operate smoothly.

It was likely that the above decision might not be easily realized. Indeed there is no clear picture today (the 
procedure has not been entirely completed) on the links between water quality management (belonging to the Ministry of Environment and Regional Development) and water management (under the Ministry of Public Transportation, Telecommunication and Water Management), the responsibility of environmental and water district authorities, and local governments, on various levels (counties, towns etc.).

It is an urgent task today in all the Central and Eastern European countries to work out proper country-wide monitoring and water quality classification systems, standards and the structure of fees and fines (as an element of a broader incentive system).

As far as the monitoring system in Hungary is considered it is one of the best organized in Europe (in terms of the number of components, frequency and spatial distribution of sampling stations, see Somlyódy et al., 1990). A revision is needed for involving parameters (and tests) of hydrobiology and ecotoxicology and increasing the confidence level of determining trends or annual average pollutant loads (even if it led to the reduction of sampling sites). The classification system should be definitely modified as it allows in its present form to draw more optimistic conclusions on the state of water environment than the reality would suggest (Somlyódy et al., 1990).

In Hungary an effluent standard system is operating with provision to define also standards for receiving waters in special cases. Total fines (for details of environmental legislation in Hungary, see Kilényi, 1990) were, in the mid-eighties, approximately 300 million $\mathrm{Ft}(\sim 6$ million USD) annually, which was not in proportion to the damages caused and did not motivate the introduction of sewage treatment (the average fine was very low, 1-3 $\times 10^{6} \mathrm{Ft}$ ). The situation was even worse in the earlier Czechoslovakia where only loosely defined imission standards were defined which were automatically met most of the time.

Clearly, the system of standards, fees and fines, and water prizing has to be fundamentally changed. Major features of such a system should be as follow.

(a) Standards should gradually approach the norms of the European Community (an immediate adjustment would be unrealistic).

(b) The elaboration of geographically non-uniform standards is recommended for the country which reflects environmental priorities and economic constraints, even if refined regulatory activity is necessitated.

(c) Simultaneously, the usage of receiving water standards are suggested whenever the fate of pollutants in recipients can be reliably evaluated (see the arguments of Thomann, 1986).

(d) Fees and fines should be significantly raised (say by an order of magnitude) to provide reasonable incentives to diminish pollutant discharges according to objectives set. They should be highly sensitive according to the nature and impact of the component considered and the synergetic effects which can occur.

The above features play a decisive role from the viewpoint of future applications of systems analysis in water pollution control in Central and Eastern Europe. If an over-simplified, uniform, effluent-standardbased regulation system were launched no need would appear for the skilled solution of highly complex, regional water pollution problems outlined earlier by using the concept and methods of systems analysis or to perform high-quality consulting work on the basis of mathematical models and decision support systems.

\section{Knowledge and experience available - Needs for training, and technology transfer}

As noted at the beginning, water quality modeling is quite well-developed in former CPE countries, at least on the research level. In a broader sense it can be said that, in contrast to developing countries, skill and scientific knowledge are available in lots of different fields, including environmental and water quality management; however these have not been utilized for solving practical problems in the past. We may 
speak about a gap in science between West and East, but the gap is much larger on the level of applications and solving real-life problems which calls for an effective technology transfer on the same level.

In Hungary, there are at least three universities offering training and courses on the environment. However, experiences of Western universities collected in the course of the past 2-3 decades have been hardly utilized. Education is too much discipline-oriented and feedback to and from practice is missing. Environmental experts from Eastern Europe are often considered as having too academic considerations: this critique is correct not only because of the lack of applications, but also because the scientific community appreciates to a lesser extent than might be desired the "engineering art of integrating" various disciplines.

It is our strong belief that if environmental legislation and institutional changes are realized properly, professionals, institutes, university departments and consulting companies will be available soon and they will advance quickly for solving water pollution control problems (by using systems analytical tools if needed) on a high level. This development will automatically induce a technology transfer from industrialized countries and a change in training.

Certainly, environmental education should be modernized systematically. It is a major issue to bring up skilled environmental and "water" engineers who have good bases in computer sciences and modeling techniques, chemistry, biology etc. in addition to traditional engineering. The role of environmental economics is stressed particularly: practically no such training exists at present in Central and Eastern European countries.

A carefully organized technology transfer would be primarily required to train future environmental administrators, officers, technicians and decision makers of district authorities and local governments as they are key persons in how management will develop in the future practice. The courses should be designed on the basis of experiences of industrialized countries with emphasize to the very special needs of Central and Eastern Europe: it is not an easy task, particularly not if we also consider the limited knowledge of Western languages of practitioners.

\section{CONCLUSION}

The final conclusion is that future applications of systems analysis in water pollution control in Central and Eastern European countries depend primarily on changes of the institutional structure and environmental legislation (including setting of intelligent standards, fees and fines and other incentives towards preventing pollution), as large number of problems exist to be solved during coming decades. Skill and knowledge are also available. Technical elements of systems analysis and water quality modeling are known too, thigh practical experiences together with the applications of environmental economics are scarce. The preparation of well defined, specific water pollution control strategies is perhaps the most important systems analytical task in all the former socialist countries in Europe.

\section{REFERENCES}

Bora, G., Hock, B., Mucsy, G., Pintér, J., Réczey, G. and Röszler, K. (1977) Water Quality Management Model of the River Sajó (in Hungarian). Hidrológiai Közlöny pp. 27-37.

Darmstadter, J. (1986) Energy patterns - in retrospect and prospect. In: W.C. Clark and R.E. Munn (eds), Sustainable Development of the Biosphere, Cambridge University Press. pp. 140-171.

EMEP (1989) Airborne transboundary transport of sulphur and nitrogen over Europe- Model descriptions and calculations. EMEP MSC-W Report 2/89.

Farkas, P. (1990) Nutrient Load Balance and Water Quality Prediction for Lake Balaton (in Hungarian). VITUKI Report(manuscript) 7612/3/1669 p. 33.

Hinrichsen, D. and Enyedi, G. (Eds.) (1990) State of the Hungarian Environment. Statistical Publishing House, Budapest. p. 143.

Hock, B. and Somlyódy, L. (1990) Freshwater Resources and Water Quality. In: State of the Hungarian Environment, D. Hinrichsen and G. Enyedi (Eds), Statistical Publishing House, Budapest, pp. 67-89.

Hornberger, G.M. and Spear, R.C. (1980) Eutrophication in Peel Inlet, I: Problem defining behaviour and a mathematical model for the phosphorus scenario. Water Research 14: pp. $29-42$.

Istvánovics, V. (1988) Seasonal variation of phosphorus release from the sediments of shallow Lake Balaton (Hungary). Water 
Research 22 (12) pp. 1473-1481.

Kilényi, G. (1990) Environmental Legislation. In: State of the Hungarian Environment, D. Hinrichsen and G. Enyedi (Eds) Statistical Publishing House, Budapest, pp. 35-45.

Kutas, T. and Herodek, S. (1986) A Complex Model for Simulating the Lake Balaton Ecosystem. In: Modeling and Managing Shallow Lake Eutrophication, L. Somlyódy and G. van Straten Eds), Springer-Verlag, Berlin, pp. 309-322.

Láng, I. (1986) Impact on Policymaking. Background to a Government Decision. In: Modeling and Managing Shallow Lake Eutrophication, L. Somlyódy and G. van Straten (Eds), Springer Verlag, Berlin, pp. 110-122.

Orlob, G.T. (1982) Mathematical Modelling of Water Quality: Streams, Lakes and Reservoirs. Wiley \& Sons, Chichester, 518 pp.

Quade, E.S. and Miser, H.J. (1985) Handbook of systems-analysis Vol. 1: Overview of uses, procedures, applications and practice. IIASA, New York: Wiley and Sons, p. 346.

Somlyódy, L. and van Straten, G. (Eds.), (1986) Modeling and Managing Shallow Lake Eutrophication. With: Application to Lake Balaton. Springer-Verlag, Berlin, p. 386.

Somlyódy, L. and Wets, R.J.-B. (1988) Stochastic Optimization Models for Lake Eutrophication Management. Operation Research Vol. 36. No .5. pp. 660-681.

Somlyódy, L., Hock, B., Zotter, K., Darázs, A., Pesti, G. and László F. (1989) Some aspects of the Gabcikovo-NagymarosBarrage System: Water Quality Models and their Applicability (in Hungarian). VITUKI Report (manuscript), research report. p. 167.

Somlyódy, L., Hock, B. and Gorzó, G. (1990) Monitoring and Evaluating Surface Water Quality: a Proposal for Revising the Existing System. Víügi Közleménrek, 2, pp. 121-141.

Straskraba, M. and Gnauck, A. (1985) Freshwater Ecosystems, Elsevier, Amsterdam, 309 pp.

Szilágyi, F., Somlyódy, L. and Koncsos, L. (1988) Chemical, biological and mass balance investigations of the Kis-Balaton reservoir (in Hungarian) VITUKI Report (manuscript), 7612/3/509 p. 195.

Thomann, R.V. (1987) Systems Analysis in Water Quality Management. A 25 Year Retrospect. In: Systems Analysis in Water Quality Management, M.B. Beck (Ed), Advances in Water Pollution Control, Pergamon Press. pp.1-14.

Thomann, R.V. and Mueller, J.A. (1987) Principles of Surface Water Quality Modeling and Control. Harper and Row, Publishers, New York. p. 644.

Uhlmann, D. (1982) Hydrobiologie, VEB Gustav Fischer Verlag, Jena, 315 pp.

UNDP/WHO Project Terminal Report (1976) Pilot Zones for Water Quality Management in Hungary. HUN/71/505-HUN/PIP001 Budapest (manuscript), p. 661. 
